\title{
Treatment of asymmetric lip with a hyaluronic acid filler
}

\section{Asimetrik dudağın hyaluronik asit dolgu ile tedavisi}

\author{
Nalan Sarac ${ }^{1}$, Gunseli Sefika Pancar ${ }^{1}$ \\ ${ }^{1}$ Dept. of Dermatology, Health Sciences University, Samsun Research and Training Hospital, Samsun, Turkey
}

\begin{abstract}
A perfectly symmetrical face is not common in human beings, and different degrees of facial asymmetry are usually present in individuals. However, asymmetric lip appearance may need to be treated, because even minor asymmetries in the central location such as lips may cause psychosocial effects negatively, although this is not apparent in some people.
\end{abstract}

Key words: dermal filler, hyaluronic acid, lip asymmetry

\section{O̊zet}

İnsanlarda mükemmel simetrik yüz görünümü nadirdir, değissik derecelerde yüz asimetrileri olabilir. Ancak bazı kişilerde belirgin olmamasına rağmen dudaklar gibi merkezi yerleşimdeki minor asimetriler bile psikososyal etkiler oluşturarak kişilerin hayatını olumsuz etkileyebildiğinden asimetrik dudak görünümün tedavi edilmesi gerekebilir.

Anahtar kelimeler: dermal dolgular, hyaluronik asit, dudak asimetrisi

\section{Introduction}

Aging-related changes such as facial volume loss, wrinkles and lines on the skin may occur over time. These changes may require treatment in dermatology as a method for reconstruction of facial deformities and restoring the aging face with dermal fillers. They are multiple fillers that are available such as various hyaluronic acid products and calcium hydroxyapatite, as well as a few others that are biocompatible with good duration and some which have a variety of mechanical properties allowing intradermal, subdermal and supraperiosteal injection. ${ }^{1,2}$

A perfectly symmetrical face is a rarity in human beings. Some degree of facial asymmetry is usually present in all individuals, even those with aesthetically attractive faces. Significant facial asymmetry causes both functional and aesthetical problems. In most cases, this asymmetry is not significant and does not require treatment. However, particularly central asymmetry, for instance in the lips, may be remarkable, and this minor lip asymmetry may have a psychosocial impact which may necessitate it to be corrected. ${ }^{2-4}$

The etiology of lip asymmetry includes congenital disorders, acquired diseases, traumatic issues, developmental deformities, improper injections of dermal fillers and postoperative repair of a cleft lip. Hyaluronic acid (HA) fillers may be used in correction of congenital and acquired lip asymmetries. ${ }^{2,3}$

Corresponding author: Nalan Sarac, Dept of Dermatology, Health Sciences University, Samsun Research and Training Hospital, Samsun, Turkey, Phone: +90 36231115 00, E-mail: dr.nalan.10@hotmail.com

Received: 19 May 2019 Accepted: 21 September 2019

Conflict of Interest: None.

This work is licensed under a Creative Commons Attribution-NonCommercial 4.0 International License. 


\section{Case report}

A 48-year-old woman was presented with the complaint of asymmetry in her upper lip. She did not have any history of trauma or operation, the lip asymmetry was congenital, and she was unhappy about it. She felt that this feature gave her an irregular smile.

Clinical examination revealed slight lengthening of the philtral ridge on the right side of the lip, deflation of the Cupid's bow and a sudden "dip" of the vermillion border on the right side, giving the appearance of a deflated right upper lip in comparison to the left side. The lower lip revealed a normal appearance (Fig. 1).

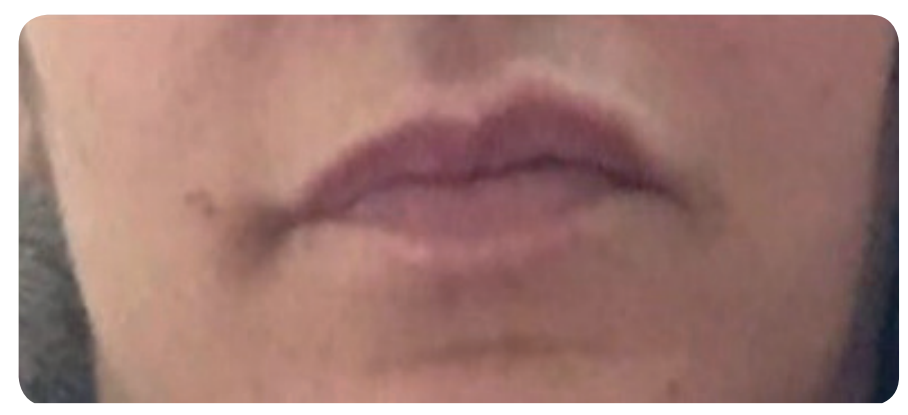

Fig. 1. Asymmetric upper lip before the treatment

There was no predisposing factor in the patient's history or family history. Her complete blood count and biochemistry tests (glucose, kidney functions, CRP, sedimentation and coagulation values) and chin X-ray were normal. She had no history of allergies.

A total of $0.5 \mathrm{~mL}$ of an $\mathrm{HA} 17.5 \mathrm{mg} / \mathrm{mL}$ soft-tissue filler was used for correction of the right side of her lip. The product was slowly administered into the right upper lip with a 30-gauge needle through three injection points. The bolus and retrograde linear threading techniques were used. We obtained a symmetrical correction with an aesthetically pleasing volume augmentation in the upper lip, and the patient was satisfied with the final outcome. No bruising, edema or other complications were recognized after the treatment (Fig. 2).

The correction of the asymmetry added positive effects on the patient's social life. It was learned that the patient

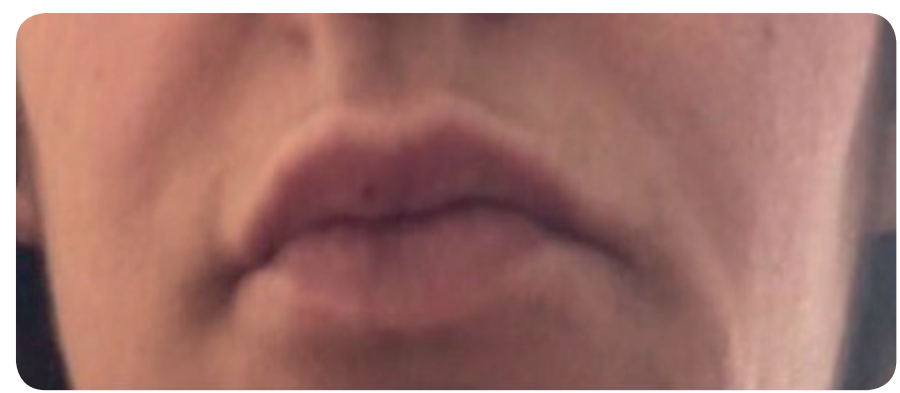

Fig. 2. A symmetrical correction in the upper lip after HA injections

gave up protective habitual tics like covering mouth with hands or avoiding laughing in her daily life. When the patient was examined 1-year after the treatment, she was still happy, and her lips appeared normal.

\section{Discussion}

Both temporary and permanent agents of various products for soft tissue fillers have been used to fill lines, wrinkles and lips. Expanded polytetrafluoroethylene, medical silicone, collagen and other nonbiodegradable fillers have been used as "minimally invasive" techniques for lip augmentation, but most of these agents are prone to adverse effects such as deformities, granulomas, allergy and nodules. For these reasons, these agents were replaced by hyaluronic acid fillers. Hyaluronic acid is now the first treatment of choice for these indications. ${ }^{1-3,5,6}$

Over the last years, injectable dermal fillers (DFs) with HA have become the most popular agents for soft tissue contouring and volumizing. HA fillers are characterized as ideal DFs due to their unique chemical-physical properties, biocompatibility, biodegradability and versatility. Therefore, HA DFs have revolutionized the filler market with a high number of products, which differ in terms of HA source, cross-linkage (agent and degree), HA concentration, hardness, cohesivity, consistency, inclusion or lack of anesthetics, indication and longevity of correction. Although soft-tissue fillers are a popular procedure worldwide today for facial lines, wrinkles and lip volume, there is limited literature on this spe- 
cific practice that is used for correction of congenital, acquired and postsurgical lip asymmetries. ${ }^{1-3,5,6}$

Schweiger et al. ${ }^{5}$ first reported the use of HA fillers for correction of residual lip asymmetry in patient after cleft lip surgery with favorable results.

Kandhari et al. ${ }^{3}$ recommended physicians to consider HA as an effective treatment for congenital, acquired and postsurgical asymmetries. In 2018, Asiran et al. ${ }^{2}$ reported dermal filler application as an effective correction method for lip asymmetry.

Hyaluronic acid fillers have water holding capacity, and by this, they improve the volume and flexibility of the dermis while also hydrating it. The structure of HA is the same in all living things, so it does not activate the immune system and may be used safely. It is biocompatible and does not cause allergic reactions. Therefore, it is the most commonly preferred agent for filler applications. ${ }^{1}$

The techniques for applying dermal fillers include point by point serial puncture, the tunnel technique or linear threading, the radial fanning technique, cross hatching, sandwich and warehouse injection techniques. The most suitable technique is chosen by the doctor according to the place and size of the application area and the type of the filler. The tunnel technique is the most preferred one. As the needle is withdrawn, a tunnel of filler is injected on the efface of the wrinkle or the area which has loss of volume. ${ }^{1}$

After application of fillers, patients should avoid hot baths and excessive physical activity, also not staying at extremely hot-cold environments. ${ }^{1}$

The goal of the treating physician should be to strive for balance to achieve an aesthetically and psychologically optimal outcome. Every patient has different facial features and needs different injection techniques, and every injection point, every HA amount should be modified according to the patient. ${ }^{1,2}$

Here, we report a 44-year-old woman with lip asymmetry which was improved by an HA dermal filler. Dermal fillers are an effective tool in correction of lip asymmetries. In some cases, even minor asymmetries may have a psychosocial impact, and after correction of these, the quality of life of patients is improved. Correction of lip asymmetries with dermal fillers has not been discussed in detail, and we need extensive scientific studies in the future.

\section{References}

1. Eken A. Injectable filler for facial aesthetic and the choice of appropriate filler agent. Turkiye Klinikleri J 2008;28:188-91.

2. Asiran SZ, Aktas KE. May dermal filler be an effective application in correcting lip asymmetries? Turkderm-Turk Arch Dermatol Venereology 2018;51:40-1.

3. Kandhari R, Goodman GJ, Signorini M, Rahman E. Use of hyaluronic asid soft-tissue filler to correct congenital and post-traumatic lip asymmetry. J Cutan Aesthet Surg 2017;10:153-6.

4. Cheong YW, Lo LJ. Facial asymmetry: etiology, evaluation, and management. Chang Gung Med J 2011;34:341-51.

5. Schweiger ES, Riddle CC, Tonkovic-Capin V, Aires DJ. Successful treatment with injected hyaluronic acid in a patient with lip asymmetry after surgical correction of cleft lip. Dermatol Surg 2008;34:717-9.

6. Brandt FS, Cazzaniga A. Hyaluronic acid fillers: Restylane and perlane. Facial Plast Surg Clin N Am 2007;15:63-76. 